\title{
Biomass estimation of Bambusa nutans subspecies nutans grown at eastern Terai, Nepal
}

\begin{abstract}
B. N. Oli ${ }^{1}$
With a view to prepare biomass table of Bambusa nutans subspecies nutans grown at Belbari, Morang district of Eastern Terai, a total of 150 culms were selected from fortyone clumps. The diametre at $15 \mathrm{~cm}$ of the base $\left(D_{15}\right)$, vertical height and green weight of the culm, branches and foliage were measured in the field. The sampled green weight was oven dried in Kathmandu. To estimate the biomass, regression model was developed on the basis of oven dry and green weight. The model used was $\operatorname{Ln}(W)=a+b \operatorname{Ln}\left(D^{2} L\right)$. Based on the oven dry weight, the $R^{2}$ values obtained for culm and total biomass components were 89 and 86 per cent respectively. However, $R^{2}$ values for the branch and foliage components were 64 and 53 per cent respectively, which were significantly lower as compared to the culm. Based on the green weight, the $R^{2}$ values obtained for culm and foliage components were 89 and 61 respectively. The validity of the equation is yet to be done.
\end{abstract}

Key words: Biomass, bamboo, Bambusa nutans subspecies nutans, Nepal

I I Nepal, Bamboos are one of the most common plant species grown on farmland. People perceive this species as an alternate to tree species. It is also considered as an important component of livelihood strategies of the rural households (Das and Oli, 2001). With its varied uses such as construction materials, woven products, agricultural implements, fodder, vegetables and scaffolding and in stabilizing slipprone slopes, bamboos are in great demand by the rural households in Nepal. Occurrence of bamboo is more common in the eastern half of the country from Dhaulagiri to Sikkim Boarder, as high as 4000 $m$ (Stapleton, 1994). As of now, twelve genera and more than fifty species of bamboo have been recorded so far in Nepal (Das, 2002).

Despite the multiple benefits obtained from bamboos, no comprehensive documentation has been published on biomass production potential. Previous studies, however, have focused on distribution, growth performance and culm production aspects. It has been reported that at 4.5 years age, the average height, diametre and survival of this species planted at Belbari of Morang district were $3.9 \mathrm{~cm}, 8 \mathrm{~m}$ and 76 per cent respectively (Thapa et al. 1998). As there is a growing demand of bamboo products in the country, the information on estimation of biomass could be beneficial for managing the bamboo resources in a more practical way. This study, therefore, aims at providing information on biomass of Bambusa nutans subspecies nutans, which is of use to forestry professionals, private growers, local forest user groups and other interested individuals.

\section{Materials and methods}

Of the five bamboo species planted by the Department of Forest Research and Survey at Belbari, Morang district in 1991, Bambusa nutans subspecies nutans was selected for the present study. The reason for selecting this species for biomass estimation is due to its multiple uses and wide occurrence in Nepal, to enrich documentation on biomass estimation of this species.

The site is located at an altitude of 155 masl and the soil is loam to silt loam. There was Sal (Shorea robusta) forest 3 to 4 years before the establishment of the trial. The average annual rainfall is $1737 \mathrm{~mm}$ and average maximum and minimum temperature are $30^{\circ}$ $\mathrm{C}$ and $18.2^{\circ} \mathrm{C}$ respectivcly (HMG/N, 1997). The plants produced from single node culm cuttings taken from Padampur and Chaughara in Hetauda, was the source of parent materials of this species. These cuttings were propagated in the Hetauda nursery before they were being taken to planting site at Belbari. Soil heaping was carried out in each clump in 1993 and the oldest culms were cut and removed in the winter of 1996 (Thapa $e t$ al., 1998).

\footnotetext{
'Assistant Biometrician, Department of Forest Research and Survey, PO box 3339, Kathmandu, NEIPAL.
E-mail: bn_oli@yahoo.com
} 
Forty-one clumps representing varying age and diametre classes were chosen. The total number of culms from each clump was counted. From each clump, at least 3 culms of various age and diametre classes totaling 150 were taken for the study. Measurements of Diameter at $15 \mathrm{~cm}$ of the base (D) ), vertical height of the culm and green weight of the culm, branches and foliage were taken in the field. The sampled green weight was oven dried in Kathmandu. A conversion factor of $0.473,0.411$ and 0.382 was used for converting green weight to oven dry weight of culm, branch and foliage respectively. To estimate the biomass, regression model was developed on the basis of oven dry weight. Biomass table for culm and foliage was also prepared on the basis of green weight. The model used was $\mathrm{L} n(\mathrm{~W})$ $=a+b \operatorname{Ln}\left(D^{2} L\right)$, where ' $W$ ' is the weight, ' $D$ ' is the diametre at $15 \mathrm{~cm}, \quad \mathrm{~L}$ ' is the vertical length of the culm, and ' $a$ ' and ' $b$ ' are the constants. Using this regression model, biomass of all the components (culm, branch, foliage and total) were calculated.

\section{Results and discussion}

Based on the oven-dried weight, the $R^{2}$ values obtained for culm and total biomass components were 89 and 86 per cent respectively. However, $R^{2}$ values for the branch and foliage components based on oven dried weight were 64 and 53 per cent respectively, which were significantly lower as compared to the culm. The dying back problems observed prior to the field measurement might have caused the lower $\mathrm{R}^{2}$ values for foliage and branch components. It is also argued that the prediction of leaf yield from biomass equations is less accurate and more site specific than for the components of stem, branch and total tree weight (Satoo and Madgwick, 1982). Biomass tables for culm, foliage and total components based on oven dried weight are presented in Table 1,2 and 3 respectively.

Biomass equations are normally prepared on an oven dry weight basis to facilitate comparison with other sites, species and seasons (Hawkins, 1987). However, bamboo culms are sold on a green weight basis in both the rural and urban areas of Nepal. So, biomass table for culm based on green weight was also prepared. Bamboo leaves are used as fodder in some areas where there is fodder deficit. Hence, biomass table for foliage was prepared on the basis of green weight. Based on the green weight, the $R^{2}$ values obtained for culm and foliage components were 89 and 61 per cent respectively. Biomass tables based on green weight for culm and foliage are given in Table 4 and 5 respectively. Rao and Nagarajaih (1991) reported from India that total biomass of planted Bambusa arundinacea (Retz.) wild of 3 years age was $8528 \mathrm{Kg}$ per ha.

Table 1: Oven dried biomass table for culm component of Bambusa nutans subspecies nutans

\begin{tabular}{|c|c|c|c|c|c|c|c|c|c|c|c|c|}
\hline \multirow{2}{*}{$\begin{array}{l}D_{15} \\
(\mathrm{~cm})\end{array}$} & \multicolumn{12}{|c|}{ Height (m) } \\
\hline & 5 & 6 & 7 & 8 & 9 & 10 & 11 & 12 & 13 & 14 & 15 & 16 \\
\hline 4 & 1.775 & 2.053 & 2.322 & 2.583 & - & - & - & -1 & -1 & - & - & $=$ \\
\hline 5 & 2.534 & 2.931 & 3.315 & 3.688 & 4.051 & - & - & - & - & - & - & - \\
\hline 6 & - & 3,921 & 4.435 & 4.933 & 5.42 & 5.895 & 6.361 & 6.818 & 7.268 & - & - & - \\
\hline 7 & - & - & 5.672 & 6.31 & 6.931 & 7.539 & 8.135 & 8.72 & 9.295 & 9.862 & 10.42 & - \\
\hline 8 & - & - & - & - & 8.578 & 9.33 & 10.07 & 10.79 & 11.5 & 12.2 & 12.89 & 13.58 \\
\hline 9 & - & - & - & - & 10.35 & 11.26 & 12.15 & 13.02 & 13.88 & 14.73 & 15.56 & 16.38 \\
\hline 10 & & - & - & - & - & 13.32 & 14.37 & 15.41 & 16.42 & 17.42 & 18.41 & 19.38 \\
\hline 11 & - & -1 & -1 & -1 & - & -1 & 16.74 & 17.94 & 19.12 & 20.29 & 21.44 & 22.57 \\
\hline
\end{tabular}

Table 2: Oven dried biomass table for foliage component of Bambusa nutans subspecies nutans

\begin{tabular}{|c|c|c|c|c|c|c|c|c|c|c|c|c|}
\hline \multirow{2}{*}{$\begin{array}{l}D_{15} \\
(\mathrm{~cm}) \\
\end{array}$} & \multicolumn{12}{|c|}{ Height (m) } \\
\hline & 5 & 6 & 7 & 8 & 9 & 10 & 11 & 12 & 13 & 14 & 15 & 16 \\
\hline 4 & 0.12 & 0.15 & 0.18 & 0.2 & - & - & - & - & - & -1 & - & \\
\hline 5 & 0.2 & 0.24 & 0.28 & 0.33 & 0.37 & -1 & & - & - & - & - & - \\
\hline 6 & - & 0.35 & 0.42 & 0.48 & 0.54 & 0.6 & 0.67 & 0.73 & 0.8 & - & - & - \\
\hline 7 & - & - & 0.57 & 0.66 & 0.75 & 0.83 & 0.92 & 1.01 & 1.1 & 1.19 & 1.28 & - \\
\hline 8 & - & - & - & - & 0.99 & 1.1 & 1.22 & 1.34 & 1.46 & 1.57 & 1.69 & 1.81 \\
\hline 9 & - & - & - & - & 1.27 & 1.41 & 1.56 & 1.71 & 1.86 & 2.01 & 2.17 & 2.32 \\
\hline 10 & & & & & - & 1.76 & 1.95 & 2.14 & 2.32 & 2.51 & 2.7 & 2.89 \\
\hline 11 & - & - & - & - & - & - & 2.38 & 2.61 & 2.84 & 3.07 & 3.3 & 3.53 \\
\hline
\end{tabular}


Table 3: Oven dried biomass table for total component of Bambusa nutans subspecies nutans

\begin{tabular}{|c|c|c|c|c|c|c|c|c|c|c|c|c|}
\hline \multirow{2}{*}{$\begin{array}{l}\mathbf{D}_{15} \\
(\mathrm{~cm})\end{array}$} & \multicolumn{12}{|c|}{ Height (m) } \\
\hline & 5 & 6 & 7 & 8 & 9 & 10 & 11 & 12 & 13 & 14 & 15 & 16 \\
\hline 4 & 2.217 & 2.587 & 2.948 & 3.302 & - & - & -1 & -1 & - & - & - & \\
\hline 5 & 3.236 & 3.777 & 4.305 & 4.821 & 5.327 & - & - & - & - & - & - & \\
\hline 6 & - & 5.146 & 5.865 & 6.568 & 7.258 & 7.936 & 8.604 & 9.263 & 9.914 & - & - & \\
\hline 7 & - & - & 7.617 & 8.530 & 9.426 & 10.307 & 11.175 & 12.031 & 12.876 & 13.711 & 14.537 & \\
\hline 8 & - & - & - & - & 11.822 & 12.927 & 14.015 & 15.089 & 16.148 & 17.196 & 18.232 & 19.257 \\
\hline 9 & - & - & - & - & 14.436 & 15.785 & 17.114 & 18.425 & 19.719 & 20.998 & 22.263 & 23.515 \\
\hline 10 & - & - & - & - & - & 18.874 & 20.463 & 22.030 & 23.577 & 25.106 & 26.619 & 28.116 \\
\hline 11 & - & - & -1 & - & & & 24.053 & 25.895 & 27.713 & 29.511 & 31.289 & 33.049 \\
\hline
\end{tabular}

Table 4: Biomass table for culm on the basis of green weight

\begin{tabular}{|c|c|c|c|c|c|c|c|c|c|c|c|c|}
\hline \multirow[t]{2}{*}{$D_{15}(\mathrm{~cm})$} & \multicolumn{12}{|c|}{ Height (m) } \\
\hline & 5 & 6 & 7 & 8 & 9 & 10 & 11 & 12 & 13 & 14 & 15 & 16 \\
\hline 4 & 3.78 & 4.37 & 4.94 & 5.5 & - & - & -1 & - & -1 & -1 & - & - \\
\hline 5 & 5.39 & 6.24 & 7.05 & 7.85 & 8.62 & $\square$ & $\ldots$ & - & - & - & - & \\
\hline 6 & & 8.34 & 9.44 & 10.5 & 11.53 & 12.54 & 13.53 & 14.51 & 15.46 & - & - & \\
\hline 7 & & - & 12.07 & 13.42 & 14.75 & 16.04 & 17.31 & 18.55 & 19.78 & 20.98 & 22.17 & \\
\hline 8 & & - & - & & 18.25 & 19.85 & 21.42 & 22.96 & 24.47 & 25.97 & 27.43 & 28.88 \\
\hline 9 & - & - & - & - & 22.02 & 23.96 & 25.85 & 27.71 & 29.54 & 31.34 & 33.11 & 34.86 \\
\hline 10 & - & - & - & - & $=$ & 28.34 & 30.58 & 32.78 & 34.94 & 37.07 & 39.17 & 41.24 \\
\hline 11 & - & - & - & - & - & - & 35.61 & 38.17 & 40.69 & 43.16 & 45.61 & 48.02 \\
\hline
\end{tabular}

Table 5: Biomass table for foliage on the basis of green weight

\begin{tabular}{|r|r|r|r|r|r|r|r|r|r|r|r|r|}
\hline $\mathbf{D}_{15}(\mathrm{~cm})$ & \multicolumn{9}{|c|}{ Height (m) } \\
\cline { 2 - 13 } & 5 & 6 & 7 & 8 & 9 & 10 & 11 & 12 & 13 & 14 & 15 & 16 \\
\hline 4 & 0.27 & 0.33 & 0.4 & 0.46 & - & - & - & - & - & - & - \\
\hline 5 & 0.45 & 0.56 & 0.66 & 0.77 & 0.88 & - & - & - & - & - & - \\
\hline 6 & - & 0.84 & 1 & 1.17 & 1.34 & 1.51 & 1.68 & 1.85 & 2.03 & - & - & - \\
\hline 7 & - & - & 1.43 & 1.66 & 1.9 & 2.14 & 2.38 & 2.63 & 2.88 & 3.14 & 3.39 & - \\
\hline 8 & - & - & - & - & 2.57 & 2.9 & 3.23 & 3.57 & 3.91 & 4.25 & 4.6 & 4.95 \\
\hline 9 & - & - & - & - & 3.36 & 3.79 & 4.22 & 4.66 & 5.11 & 5.56 & 6.01 & 6.47 \\
\hline 10 & - & - & - & - & - & 4.82 & 5.37 & 5.93 & 6.49 & 7.06 & 7.64 & 8.22 \\
\hline 11 & - & - & - & - & - & - & 6.67 & 7.36 & 8.06 & 8.77 & 9.49 & 10.21 \\
\hline
\end{tabular}

\section{Applicability of the table}

Considering the wide use of bamboos these days, the biomass tables may help provide useful information on above ground biomass to forestry professional, bamboo growers, forest user groups and other interested individuals. The biomass estimation is confined to the site condition of Belbari of Morang district. Moreover, some management practices such as soil heaping and removal of the oldest culms were carried out in the past. Hence, the above tables may not necessarily represent the Bambusa nutans subspecies nutans grown at other site conditions and management prescriptions. Validity of the equation is yet to be done. Hence, it is recommended to pretest the table before applying to other site conditions.

\section{Acknowledgement}

I am grateful to Mr. A. V. Parajuli, Director General of Department of Forest Research and Survey for his encouragement for this study. Thanks are due to Dr. A. N. Das, Mr. H. B. Thapa and Mr. K. P. Acharya for their comments on this paper. I would also like to thank Mr. Basanta Sharma for assisting the field work. 


\section{References}

Das, A. N. and Oli, B. N. 2001. Tree growing practices on farmland: an option for sustaining rural livelihoods. Banko Janakari 11 (2): 8-12.

Das, A. N. 2002. Manual of Bamboos in Nepal. A Draft Report submitted to Tree Improvement and Silviculture Component (TISC). Kathmandu, Nepal.

Hawkins, T. 1987. Biomass and volume tables for Eucalyptus camaldulensis, Dalbergia sissoo, Acacia auriculiformis and Cassia siamea in the Central Bhabar-Terai of Nepal. O. F. I. Occasional Papers No. 33. Oxford Forestry Institute, UK.

HMG/N. 1997. Climatological Records of Nepal 1991-1994. Kathmandu, Nepal.
Rao, N. S. and Nagarajaih, C. 1991. Evaluation of Bambusa arundinacea (Retz.) wild for growth and biomass production in dryland ecosystem. MYFOREST 27 (1):70-74.

Satoo, T. and Madgwick, H. 1982. Forest Biomass. The Hague: Martinus Nijhoff/Dr. W. Junk. 150 p.

Stapleton, C. M. A. 1994. Bamboo of Nepal: an illustrated guide. Royal Botanical Garden, Kew, UK.

Thapa, H. B.; Das, A. N. and Oli, B. N. 1998. Growth performance and culm production of bamboo at the eastern Terai, Nepal. Banko Janakari 8 (1): 1318. 